\title{
Ship row flags up funding of war in Africa
}

Rex Dalton, San Diego

The flag that flutters atop the JOIDES Resolution, one of the world's premier scientific ships, does not represent any of the more than 20 nations that have funded her decades of journeys on the seven seas. Instead it is the banner of Liberia - a West African country that has diverted funds from its fat ship-registration coffers to fund arms purchases for civil wars.

The Resolution, like many other ships, flies under this flag of convenience in order to limit taxes, while operating under fewer regulations for safety and crew working conditions.

But human-rights organizations have discovered in recent years that Liberia and neighbouring countries have used money from shipping registration to fund conflicts noted for their use of child soldiers. This has prompted some commercial ship owners to shift their registration elsewhere. Now a growing number of scientists are hoping that the owners of the Resolution will follow suit.

The Resolution's scientific cruises are managed by the Joint Oceanographic Institutions (JOI), a Washington-based consortium of 18 public institutes that receive funds from the US National Science Foundation (NSF). In September, the JOI won a ten-year, \$625-million contract from the NSF to manage the US component of the Integrated Ocean Drilling Program (IODP), an international drilling endeavour (see page 492).

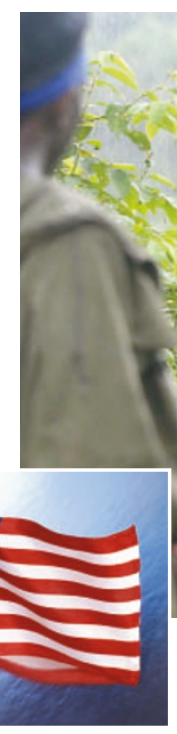

The JOI learned of the concerns about Liberian registry at least two years ago, when a former third mate from the Resolution wrote to US Senator Michael Enzi and Representative Barbara Cubin, both Republicans from Wyoming, complaining about the use of NSF funds for a Liberian ship registry. The mate branded the practice un-American, and claimed that it exploited crewmen from developing nations. "The NSF and the American taxpayer should never fund a ship that does not fly the flag of the USA," the mate wrote.

JOI president Steven Bohlen says that the seaman was a "disgruntled employee" who was discharged because of limited skills. And both the JOI and the Resolution's owners insisted that the ship was operated safely under Liberian rules. The members of Congress took no action. Neither did the JOI or the NSF, whose officials say that the agency does not have a position on the issue.

But as the Resolution prepares to sail for the IODP, concerns are re-emerging from scientists, who wish to remain anonymous, that scientific funds from the United States, Japan and Europe are continuing to go to Liberia. They say that few researchers associated with the IODP are familiar with the issue, but that many of those who are feel strongly about a change in registration.

Bohlen says that his agency has been too busy developing the IODP to address the issue of ship registry. But Guy Cantwell, a spokesman for Transocean, the world's largest offshore drilling firm, which is based in Houston, Texas, and co-owns the Resolution, says: "We are aware that this is an issue in the scientific community." After Nature contacted Transocean, Cantwell said that the firm is considering switching the Resolution's registration to a more politically palatable low-tax nation, such as the Marshall Islands in the Pacific.

\section{Budget cuts force Hong Kong to reduce salaries}

\section{Carina Dennis, Singapore}

Scientists in Hong Kong are bracing themselves for a wave of salary cuts as the government reduces university funding next year by nearly $10 \%$ from last year's figure.

Staff salaries are expected to be hit hardest. Research funding, which is overseen by the Research Grants Council, has so far been spared cuts. But researchers worry that low salaries will drive some people away, leaving fewer to teach and giving the remaining staff less time for research.

On 26 November, the University Grants Committee issued a statement outlining the $9.7 \%$ reduction for $2004-05$. The cuts, which total about HK\$1.1 billion (US\$140 million), are part of a strategy of the Hong Kong Special Administrative Region government to reduce expenditure to soothe the region's troubled economy, which was battered by the SARS epidemic.
University funding in Hong Kong is usually decided for three years at a time the last budget covered 2001-04. But the government decided to set the upcoming budget for only a single year, following a review of the higher-education sector that recommended that the region's eight universities diversify into their areas of strength.

"We decided to give the University Grants Committee a year to prepare new funding models and to give the universities time to focus on differentiating their roles," says Arthur Li, Hong Kong's secretary for education and manpower. In the meantime, the government is encouraging universities to make up some of the shortfall through fundraising, with a HK\$1-billion scheme to match funds obtained from other sources.

The government will not comment on whether there will be additional cuts in the next three-year budget, but many researchers are concerned about the future. “A lot of young people don't know if their contracts will be renewed or what their career future will be in Hong Kong," says Kathy Cheah, who heads the University of Hong Kong's biochemistry department.

But not everyone is being driven away by the budget problems. Lap-Chee Tsui took up the position of vice-chancellor at the University of Hong Kong last year after serving as chief geneticist at the Hospital for Sick Children in Toronto, Canada. "The main reason I came back was to contribute to the education sector. I didn't expect the budget situation to be as it is but I'm happy to be part of solving the problem," he says.

"Even though it is a difficult economic time, I hope that the government won't be so short-sighted as to cut our roots so we can't grow in the future," adds Tsui. 